\title{
THE EFFECT OF THE TYPES OF FOLIAR FEEDING ON FRESH AND DRY WINTER RAPE MASS (BRASSICA NAPUS L.)
}

\author{
SIKORSKA, A. ${ }^{1}-$ GUGAŁA, M. $^{2 *}-$ ZARZECKA, $^{*}{ }^{2}$ \\ ${ }^{1}$ Department of Agriculture, State Higher Vocational School in Ciechanów \\ ul. Narutowicza 9, 06-400 Ciechanów, Poland \\ (e-mail:anna.sikorska@pwszciechanow.edu.pl) \\ ${ }^{2}$ Department of Agrotechnology, Siedlce University of Natural Sciences and Humanities \\ ul. Prusa 14, 08-110 Siedlce, Poland \\ (e-mail:kzarzecka@uph.edu.pl) \\ *Corresponding author \\ e-mail: gugala@uph.edu.pl \\ (Received $28^{\text {th }}$ Feb 2019; accepted $10^{\text {th }}$ Apr 2019)
}

\begin{abstract}
The field experiment was carried out in 2016-2019 at the Agricultural Experimental Station Zawady belonging to the University of Natural Sciences and Humanities in Siedlce. The experiment was established in a random split-plot system in three repetitions. The surface of one plot was $21 \mathrm{~m}^{-2}$. The examined factors were I - three varieties of winter rape: Monolit (population variety), PX115 (hybrid variety restored with a semi-dwarf growth type), PT248 (hybrid variety restored with a traditional growth type). II - four types of foliar feeding: 1. control object (without foliar feeding and biostimulator were sprayed with distilled water), 2. biostimulator Aminoplant, 3. Foliar fertilizer Siarkomag + foliar fertilizer Bormax, 4. Foliar fertilizer Siarkomag + foliar fertilizer Bormax + biostimulator Aminoplant. The aim of the study was to determine the effect of foliar feeding on the growth of fresh and dry mass of plants (leaf rosette, root) of three winter rape varieties. On the basis of the conducted research, it was found that autumn foliar feeding of plants significantly increased the fresh and dry weight of the rosette and the root system in comparison to the control variant. The highest growth of plant weight and root system was recorded on object 4, which proves that the biostimulator applied with foliar fertilizers had a positive effect on the uptake and accumulation of micro and macro-elements provided with foliar fertilizers. The Monolit population variety was distinguished by the largest green and dry mass of the rosette and root system. In the growing season 2018-2019 characterized by very hot and dry autumn, the largest fresh and dry mass of plants (rosettes and root system) was found.
\end{abstract}

Keywords: morphotype, leaf rosette, root, foliar fertilization, biostimulator, amino acids

\section{Introduction}

Insufficient feeding of plants leads to the disturbances of basic physiological processes, which adversely affects the growth and development of plants, contributing as a consequence to a decrease in yields (Kocot and Grenda, 2004). SienkiewiczCholewa and Kieloch (2015) and Jankowski et al. (2016b) they emphasize that during the growing season some nutrients can be delivered directly on the plant leaves.

Foliar feeding of plants supplying, in addition to the necessary nutrients, biostimulator compounds, is more and more often treated as permanent elements of the proper agrotechnology of many crop plants. According to Harris et al. (2018) the foliar application is the fastest method of providing nutrients for plants.

Szewczuk (2003) and Kocoń (2009) in their research emphasized the beneficial effect of foliar nutrition in winter plants in the period of autumn growing season.

The macro and microelements provided at the time influence the accumulation of sugars in plant cells, which is associated with the hardening of plants and increased 
resistance to wintering conditions (Szewczuk and Sugier, 2009). Noreen et al. (2018) and Yakhin et al. (2017) they stated that plants well fed with essential nutrients have greater tolerance to environmental stress.

According to Jankowski et al. (2016a) and White et al. (2015) foliar fertilization is an alternative method of providing macro-elements, it can be used only to reverse the effects of nutritional deficiencies and can serve as the main technique of fertilization only to provide plants with the required micronutrients.

Kocira et al. (2016) and Złotek and Wójcik (2014) biostimulators and agents containing micronutrient additives are safe to use and do not exhibit any destructive effects on the environment.

The study assumes the hypothesis that the use of foliar fertilizers and biostimulators may affect the growth of fresh and dry mass of plants (rosettes, root system). The aim of the research was to determine the effect of foliar nutrition on the growth of fresh and dry mass of the aboveground part of the rosette and fresh and dry mass of the root system of three varieties of winter rape.

\section{Materials and methods}

\section{Experimental and agronomic management}

The field experiment was carried out in 2016-2019 at the Agricultural Experimental Station Zawady $\left(52^{\circ} 03^{\prime} \mathrm{N}\right.$ and $\left.22^{\circ} 33^{\prime} \mathrm{E}\right)$ belonging to the University of Natural Sciences and Humanities in Siedlce. The experiment was established in a random split-plot system in three repetitions. The surface of one plat was $21 \mathrm{~m}^{-2}$.

The following factors were studied in the experiment:

Factor I - three varieties of rape:

1. Monolit (population variety)

2. PT 248 (hybrid variety restored with a traditional growth type)

3. PX 115 (hybrid variety restored with a semi-dwarf growth type)

Factor II - four types of foliar feeding:

1. Control object - without using foliar feeding and a biostimulator were sprayed with distilled water

2. Biostimulator Aminoplant $\left(\mathrm{N}_{\text {total }}-8.5 \%\right)$ : I term - in autumn in the 4-6 leaf phase (BBCH 14-16) at a dose of $1.0 \mathrm{dm}^{3} \cdot \mathrm{ha}^{-1}$

3. Foliar fertilizer Siarkomag $\left(\mathrm{MgO}-5 \% . \mathrm{SO}_{3 \text { total }}-85 \% . \mathrm{SO}_{3 \text { soluble }}\right.$ in water $10 \%)+$ foliar fertilizer Bormax (B - 11\%): I term - in autumn in the 4-6 leaf phase (BBCH 14-16) at a dose of $2.0 \mathrm{dm}^{3} \cdot \mathrm{ha}^{-1}+0.5 \mathrm{dm}^{3} \cdot \mathrm{ha}^{-1}$

4. Foliar fertilizer Siarkomag + foliar fertilizer Bormax + biostimulator Aminoplant: I term - in autumn in the 4-6 leaf phase (BBCH 14-16) at a dose of $2.0 \mathrm{dm}^{3} \cdot \mathrm{ha}^{-1}+0.5 \mathrm{dm}^{3} \cdot \mathrm{ha}^{-1}+1.0 \mathrm{dm}^{3} \cdot \mathrm{ha}^{-1}$

The forecrop for winter rape in particular years of the research was spring wheat $(1 \mathrm{st}$ year of research), winter triticale (2nd year of research), winter triticale ( 3 rd year of research). The experiment was carried out on soil classified in the order of soils with clay translocation, type - Luvisols, subtype - Albic Luvisols (WBR FAO 2014). This soil was classified as IVa bonitation class soil, of very good rye complex for agricultural use. During the years of the experiment, soil $\mathrm{pH}$ (in $1 \mathrm{n} \mathrm{KCl}$ ) was slightly acidic, ranging from 5.68 to 5.75 . The soil was characterized by a low total content of nitrogen (on 
average $0.85 \mathrm{~g} \cdot \mathrm{kg}^{-1}$ ), phosphorus (on average $0.44 \mathrm{~g} \cdot \mathrm{kg}^{-1}$ ), potassium (on average 0.65 $\mathrm{g} \cdot \mathrm{kg}^{-1}$ ) and calcium (on average $0.83 \mathrm{~g} \cdot \mathrm{kg}^{-1}$ ) and the medium content of magnesium (on average $0.42 \mathrm{~g} \cdot \mathrm{kg}^{-1}$ ) and sulphur (on average $0.13 \mathrm{~g} \cdot \mathrm{kg}^{-1}$ ). It demonstrated low content of available phosphorus forms (on average from 75 to $80 \mathrm{mg} \cdot \mathrm{kg}^{-1}$ ) and medium content of available forms of potassium (on average from 200 to $205 \mathrm{mg} \cdot \mathrm{kg}^{-1}$ ) and magnesium (on average from 59 to $61 \mathrm{mg} \cdot \mathrm{kg}^{-1}$ ).

After forecrop harvest, a set of post-harvest procedures was carried out using the ploughing aggregate + open cage roller, and then two weeks after the first procedure, pre-sow ploughing at the depth of $20.0 \mathrm{~cm}$ was carried out, using a ring roller at the same time. To prepare the soil for sowing and to mix fertilizers, a complex soil tillage unit was used. Before sowing, phosphorus-potassium fertilization was applied at the dose of $40 \mathrm{~kg} \mathrm{P} \cdot \mathrm{ha}^{-1}$ and $110 \mathrm{~kg} \mathrm{~K} \cdot \mathrm{ha}^{-1}$ and the first dose of $40 \mathrm{~kg} \mathrm{~N} \cdot \mathrm{ha}^{-1}$. Fertilization was applied in the form of Lubofos at the dose of $600 \mathrm{~kg}$. Fertilizing doses were supplemented with $55.9 \mathrm{~kg} \cdot \mathrm{ha}^{-1}$ of ammonium nitrate $\left(19 \mathrm{~kg} \mathrm{~N} \cdot \mathrm{ha}^{-1}\right), 29.6 \mathrm{~kg} \cdot \mathrm{ha}^{-1}$ triple superphosphate $\left(13.6 \mathrm{~kg} \mathrm{P} \cdot \mathrm{ha}^{-1}\right)$ and $29 \mathrm{~kg} \cdot \mathrm{ha}^{-1}$ potassium salt $\left(17.9 \mathrm{~kg} \mathrm{~K} \cdot \mathrm{ha}^{-1}\right)$. The second dose of nitrogen in the amount of $100 \mathrm{~kg} \cdot \mathrm{ha}^{-1}$ was applied in spring, before vegetation started (BBCH 28-30) applying ammonium nitrate at the dose of $255.5 \mathrm{~kg} \cdot \mathrm{ha}^{-1}\left(86.9 \mathrm{~kg} \mathrm{~N} \cdot \mathrm{ha}^{-1}\right)$ and ammonium sulphate at the dose of $62.5 \mathrm{~kg} \cdot \mathrm{ha}^{-1}$. The third dose of ammonium $60 \mathrm{~kg} \cdot \mathrm{ha}^{-1}$ was applied at the inflorescence emergence $(\mathrm{BBCH}$ $50)$ by applying ammonium nitrate at the dose of $176.5 \mathrm{~kg} \cdot \mathrm{ha}^{-1}\left(60 \mathrm{~kg} \mathrm{~N} \cdot \mathrm{ha}^{-1}\right)$.

Winter rapeseed sowing was made at spacing between rows of $22.5 \mathrm{~cm}$, assuming the sow of $60 \mathrm{pcs} \cdot \mathrm{m}^{-2}$. Sowing was made at the optimal time recommended for this region (in 2016 - on 12 August, 2017 - on 14 August, and in 2018 - on 13 August).

Chemical protection against weeds, diseases and pests was applied in accordance with the recommendations of good agricultural practice.

Immediately before the inhibition of the autumn vegetation the following biometric characteristics were identified on the randomly selected sample of 20 plants:

- Fresh mass of the aboveground part of 1 rosette $(\mathrm{g})$

- Dry mass of the aboveground part of 1 rosette $(\mathrm{g})$

- Fresh mass of the root system of 1 plant (g)

- Dry mass of the root system of 1 plant $(\mathrm{g})$

In all years of conducting experiments, plant samples were collected in the 16-19 $\mathrm{BBCH}$ phase, in the second decade of October.

The method of determining air dry matter in fresh plant material consisted in drying the sample to air-dry state in a natural way, and then at a temperature not exceeding $105{ }^{\circ} \mathrm{C}$ for $3 \mathrm{~h}$.

\section{Statistical analysis}

The results of the study were statistically analysed with the use of the analysis of variance. The significance of variation sources was tested with the "F" FischerSnedecor test and the assessment of significance at the significance level of $p=0.05$ between compared means with Tukey's range test.

\section{Weather conditions}

In autumn, varied weather conditions prevailed in the analysed vegetation seasons (Table 1). In the first year of research, autumn was quite dry $(\mathrm{K}=1.30)$. The period 
from August to October was characterized by a smaller average of $11.3 \mathrm{~mm}$ of rainfall compared to the average of that period from 1996-2010, while the average air temperature was similar to the long-term period of $13.3{ }^{\circ} \mathrm{C}$. In the growing season of 2017-2018 based on the calculated Sielianinow coefficient (Skowera, 2014), it was found that autumn was quite wet $(\mathrm{K}=1.76)$. The sum of precipitation from August to October was higher by an average of $61.9 \mathrm{~mm}$ compared to the average for many years, and the average air temperature was higher by $0.5{ }^{\circ} \mathrm{C}$. In the last year of research, autumn was very dry $(\mathrm{K}=0.68)$. The sum of precipitation from August to October was lower by $51.2 \mathrm{~mm}$ compared to the long-term, and the average air temperature was higher on average by $2.1^{\circ} \mathrm{C}$ compared to many years.

Table 1. Characteristics of weather conditions in the years 2016-2019 (Zawady Meteorological Station, Poland)

\begin{tabular}{|c|c|c|c|c|c|c|c|c|}
\hline \multirow{3}{*}{ Months } & \multicolumn{4}{|c|}{ Rainfalls (mm) } & \multicolumn{4}{|c|}{ Air temperature $\left({ }^{\circ} \mathrm{C}\right)$} \\
\hline & \multirow{2}{*}{$\begin{array}{c}\text { Multiyear sum } \\
1996-2010\end{array}$} & \multicolumn{3}{|c|}{\begin{tabular}{|l|} 
Monthly sum \\
\end{tabular}} & \multirow{2}{*}{$\begin{array}{c}\text { Multiyear mean } \\
1996-2010\end{array}$} & \multicolumn{3}{|c|}{ Monthly mean } \\
\hline & & 2016-2017 & $2017-2018$ & 2018-2019 & & 2016-2017 & 2017-2018 & $2018-2019$ \\
\hline VIII & 59.9 & 31.7 & 54.7 & 24.5 & 18.5 & 18.0 & 18.4 & 20.6 \\
\hline IX & 42.3 & 13.6 & 80.6 & 27.4 & 13.5 & 14.9 & 13.9 & 15.9 \\
\hline $\mathrm{X}$ & 24.2 & 69.8 & 53.0 & 23.3 & 7.9 & 7.0 & 9.0 & 9.6 \\
\hline $\mathrm{XI}$ & 20.2 & 19.5 & 21.3 & 9.8 & 4.0 & 2.4 & 4.1 & 7.9 \\
\hline XII & 18.6 & 22.5 & 15.8 & 9.0 & -0.1 & 0.0 & 2.7 & 0.3 \\
\hline I & 19.0 & 0.4 & 10.1 & 7.9 & -3.2 & -6.6 & -0.7 & -3.0 \\
\hline Mean & 184.2 & 157.5 & 235.5 & 101.9 & 12.1 & 5.9 & 7.9 & 8.5 \\
\hline \multicolumn{9}{|c|}{ Sielianinovs hydrothermic coefficients* } \\
\hline & \multicolumn{2}{|c|}{ 2016-2017 } & \multicolumn{3}{|c|}{$2017-2018$} & \multicolumn{3}{|c|}{ 2018-2019 } \\
\hline VIII & \multicolumn{2}{|c|}{0.61} & \multicolumn{3}{|c|}{1.00} & \multicolumn{3}{|c|}{0.40} \\
\hline IX & \multicolumn{2}{|l|}{0.28} & \multicolumn{3}{|c|}{1.92} & \multicolumn{3}{|c|}{0.71} \\
\hline $\mathrm{X}$ & \multicolumn{2}{|l|}{3.02} & \multicolumn{3}{|c|}{2.36} & \multicolumn{3}{|c|}{0.94} \\
\hline Mean & \multicolumn{2}{|l|}{1.30} & \multicolumn{3}{|c|}{1.76} & \multicolumn{3}{|c|}{0.68} \\
\hline
\end{tabular}

*Index value (Skowera, 2014): extremely dry $\mathrm{k} \leq 0.4$, very dry $0.4<\mathrm{k} \leq 0.7$, dry $0.7<\mathrm{k} \leq 1.0$, rather dry $1.0<\mathrm{k} \leq 1.3$, optimal $1.3<\mathrm{k} \leq 1.6$, rather humid $1.6<\mathrm{k} \leq 2.0$, humid $2.0<\mathrm{k} \leq 2.5$, very humid $2.5<\mathrm{k} \leq 3.0$, extremely humid $\mathrm{k}>3.0$

\section{Results and discussion}

On the basis of the conducted research, it was found that the applied foliar nutrition significantly influenced the increase of fresh and dry mass of the aboveground part of the rosette and root system in comparison to the control variant (Tables 2, 4, 6 and 7). This is consistent with the results of Gawrońska et al. (2008) and Sikorska et al. (2017). The authors after using biostimulators Asahi SL, Tytanit and Silvit noted an increase in the value of these features compared to the control object. Albayrak and Camas (2005), Soheir et al. (2012) and Aisha et al. (2014) under the influence of stimulation with humic acids received a greater fresh and dry mass of the aboveground part of the rosette and root system in comparison of the object on which no fertilization was applied. Similarly, Krawczyk and Skoczyński (2008) showed a beneficial effect of the foliar fertilizer Route on the fresh and dry mass of the root system. In own studies, the largest increase in plant mass and root system was noted on object 4 , where the foliar fertilizer Siarkomag. Bormax and biostimulator Aminoplant were used. This proves that the applied biostimulator positively influenced the uptake and accumulation of micro and macro-elements provided with foliar fertilizers. In our own research, the genetic factor 
significantly affected the fresh and dry mass of aboveground part of the rosette and root system. The highest values of the discussed features were found in the Monolit population variety, while the lowest in the restored hybrid with a semi-dwarf growth type (PX 115) (Tables 2, 4, 6 and 7). This is in line with the results of studies by Kotecki et al. (2007) and Sikorska et al. (2017). These authors also recorded the largest fresh and dry mass of the aboveground part of the rosette and root system in the Monolit population variety, while the smallest in the semi-dwarf PR44D06. Similarly, Wielebski and Wójtowicz (2018) showed that the hybrid morphotype with a semi-dwarf growth type PR45D03 was characterized by a smaller fresh mass compared to the varieties with a traditional type of growth: hybrid Poznaniak and population Starter. Jankowski and Budzyński (2007) and Wielebski (2007) came to different conclusions, who showed that hybrid forms produced a rosette with a larger fresh and dry mass of 1 plant and the root system. The largest fresh and dry mass of the above-ground of 1 rosette and the root system was noted in the last year of research, in which autumn was very dry and warm, while the lowest in the fairly humid vegetation season 2017-2018 (Tables 2, 4, 6 and 7). In turn, in earlier studies by Sikorska et al. (2017), the highest values of the discussed features were demonstrated in the season characterized by heavy rainfall in August and alternate rainfall in September and higher than the average air temperature in September and October, while the lowest in the season in which strong drought occurred in August and the first two decades of September.

Table 2. Green matter of one plant (g) depending on factors of experience

\begin{tabular}{|c|c|c|c|c|c|c|c|c|}
\hline \multirow[b]{4}{*}{ Cultivars } & \multirow{3}{*}{\multicolumn{3}{|c|}{ Years }} & \multicolumn{4}{|c|}{ Types of foliar feeding } & \multirow[b]{4}{*}{ Mean } \\
\hline & & & & \multicolumn{4}{|c|}{ Objects } & \\
\hline & & & & 1. & 2. & \multirow{2}{*}{$\begin{array}{c}3 . \\
\text { Foliar fertilizer } \\
\text { Siarkomag }+ \\
\text { foliar fertilizer } \\
\text { Bormax }\end{array}$} & \multirow[b]{2}{*}{$\begin{array}{c}4 . \\
\text { Foliar fertilizer } \\
\text { Siarkomag + foliar } \\
\text { fertilizer Bormax }+ \\
\text { biostimulator } \\
\text { Aminoplant }\end{array}$} & \\
\hline & 2016-2017 & $2017-2018$ & 2018-2019 & $\begin{array}{l}\text { Control } \\
\text { variant }\end{array}$ & $\begin{array}{c}\text { Biostimulator } \\
\text { Aminoplant }\end{array}$ & & & \\
\hline Monolit & 34.708 & 27.542 & 41.033 & 32.533 & 32.833 & 35.733 & 36.611 & $34.428 \mathrm{a}$ \\
\hline PT 248 & 31.650 & 25.458 & 35.800 & 29.322 & 29.933 & 31.600 & 33.022 & $30.969 \mathrm{~b}$ \\
\hline PX 115 & 27.083 & 23.075 & 32.508 & 25.811 & 26.467 & 28.256 & 29.689 & $27.556 \mathrm{c}$ \\
\hline Mean & $31.147 \mathrm{a}$ & $25.358 \mathrm{~b}$ & $36.447 \mathrm{c}$ & $29.222 \mathrm{a}$ & $29.744 \mathrm{~b}$ & $31.863 \mathrm{c}$ & $33.107 \mathrm{~d}$ & - \\
\hline
\end{tabular}

$\mathrm{LSD}_{0.05}$ for: years - 0.460 ; cultivars - 0.460 ; types of foliar feeding - 0.331 ; interaction: years $\mathrm{x}$ cultivars -0.796 ; cultivars $\mathrm{x}$ types of foliar feeding -0.522

The statistical calculations showed the interaction of years and studied varieties with the fresh and dry matter of the aboveground part of 1 rosette and the root system, which means that varieties reacted to the humidity and thermal conditions differently in the years of research (Tables 2, 4, 6 and 7). Based on the conducted studies, the interaction of varieties and types of foliar feeding was found, which means that varieties reacted differently to the types of foliar feeding (Tables 2 and 4). The fresh and dry mass of the above ground part of 1 rosette of the Monolit variety after the application of the Aminoplant biostimulator containing amino acids was the same as in the control object. In all studied varieties, the highest increase in fresh and dry matter was recorded as a result of the application of the Aminoplant biostimulator with foliar fertilizers Siarkomag and Bormax. The impact of biostimulators and foliar fertilizers on the fresh and dry mass of the aboveground part of 1 rosette was determined by the climatic 
conditions prevailing in the years of research (Tables 3 and 5). In autumn in the growing seasons 2017-2018 and 2018-2019, the fresh mass of aboveground part of rosette after the application of the Aminoplant biostimulator was the same as in the control object, while the dry mass of the aboveground part after using the bioregulator with the amino acid was the same as in the control object only in the last growing season.

Table 3. Green matter of one plant $(g)$ depending on the years and types of foliar feeding

\begin{tabular}{|c|c|c|c|c|c|}
\hline \multirow{4}{*}{ Years } & \multicolumn{4}{|c|}{ Types of foliar feeding } & \multirow{4}{*}{ Mean } \\
\hline & \multicolumn{4}{|c|}{ Objects } & \\
\hline & 1. & 2. & 3. & 4. & \\
\hline & Control variant & $\begin{array}{c}\text { Biostimulator } \\
\text { Aminoplant }\end{array}$ & $\begin{array}{c}\text { Foliar fertilizer } \\
\text { Siarkomag + foliar } \\
\text { fertilizer Bormax }\end{array}$ & $\begin{array}{c}\text { Foliar fertilizer } \\
\text { Siarkomag }+ \text { foliar } \\
\text { fertilizer Bormax }+ \\
\text { biostimulator Aminoplant }\end{array}$ & \\
\hline $2016-2017$ & $29.611 \mathrm{a}$ & $30.189 \mathrm{~d}$ & $31.944 \mathrm{~g}$ & $32.844 \mathrm{j}$ & 31.147 \\
\hline $2017-2018$ & $23.356 \mathrm{~b}$ & $23.867 \mathrm{~b}$ & $26.367 \mathrm{~h}$ & $27.844 \mathrm{k}$ & 25.358 \\
\hline 2018-2019 & $34.700 \mathrm{c}$ & $35.178 \mathrm{c}$ & $37.278 \mathrm{i}$ & 38.6331 & 36.447 \\
\hline Mean & 29.222 & 29.744 & 31.863 & 33.107 & - \\
\hline
\end{tabular}

$\mathrm{LSD}_{0.05}$ for: years - 0.460 ; types of foliar feeding - 0.331 ; interaction: years $\mathrm{x}$ types of foliar feeding -0.522

Table 4. Dry matter of one plant ( $g$ ) depending on factors of experience

\begin{tabular}{|c|c|c|c|c|c|c|c|c|}
\hline \multirow[b]{4}{*}{ Cultivars } & \multirow{3}{*}{\multicolumn{3}{|c|}{ Years }} & \multicolumn{4}{|c|}{ Types of foliar feeding } & \multirow[b]{4}{*}{ Mean } \\
\hline & & & & \multicolumn{4}{|c|}{ Objects } & \\
\hline & & & & 1. & 2. & 3. & 4. & \\
\hline & 2016-2017 & $2017-2018$ & 2018-2019 & $\begin{array}{l}\text { Control } \\
\text { variant }\end{array}$ & $\begin{array}{c}\text { Biostimulator } \\
\text { Aminoplant }\end{array}$ & $\begin{array}{c}\text { Foliar fertilizer } \\
\text { Siarkomag }+ \\
\text { foliar fertilizer } \\
\text { Bormax }\end{array}$ & $\begin{array}{c}\text { Foliar fertilizer } \\
\text { Siarkomag + foliar } \\
\text { fertilizer Bormax }+ \\
\text { biostimulator } \\
\text { Aminoplant }\end{array}$ & \\
\hline Monolit & 7.633 & 6.058 & 9.075 & 7.144 & 7.222 & 7.889 & 8.100 & $7.589 \mathrm{a}$ \\
\hline PT 248 & 6.958 & 5.600 & 7.867 & 6.433 & 6.556 & 6.956 & 7.289 & $6.808 \mathrm{~b}$ \\
\hline PX 115 & 5.950 & 5.067 & 7.208 & 5.711 & 5.844 & 6.211 & 6.533 & $6.075 \mathrm{c}$ \\
\hline Mean & $6.847 \mathrm{a}$ & $5.575 \mathrm{~b}$ & $8.050 \mathrm{c}$ & $6.430 \mathrm{a}$ & $6.541 \mathrm{~b}$ & $7.019 \mathrm{c}$ & $7.307 \mathrm{~d}$ & - \\
\hline
\end{tabular}

$\mathrm{LSD}_{0.05}$ for: years - 0.097; cultivars - 0.097; types of foliar feeding - 0.065; interaction: years x cultivars - 0.169; cultivars x types of foliar feeding - 0.102

Table 5. Dry matter of one plant ( $g$ ) depending on the years and types of foliar feeding

\begin{tabular}{|c|c|c|c|c|c|}
\hline \multirow{4}{*}{ Years } & \multicolumn{4}{|c|}{ Types of foliar feeding } & \multirow{4}{*}{ Mean } \\
\hline & \multicolumn{4}{|c|}{ Objects } & \\
\hline & 1. & 2. & 3. & 4. & \\
\hline & Control variant & $\begin{array}{l}\text { Biostimulator } \\
\text { Aminoplant }\end{array}$ & $\begin{array}{c}\text { Foliar fertilizer Siarkomag } \\
+ \text { foliar fertilizer Bormax }\end{array}$ & $\begin{array}{c}\text { Foliar fertilizer Siarkomag } \\
+ \text { foliar fertilizer Bormax } \\
\text { + biostimulator } \\
\text { Aminoplant }\end{array}$ & \\
\hline $2016-2017$ & $6.500 \mathrm{a}$ & $6.644 \mathrm{~d}$ & $7.022 \mathrm{f}$ & $7.222 \mathrm{i}$ & 6.847 \\
\hline $2017-2018$ & $5.133 \mathrm{~b}$ & $5.244 \mathrm{e}$ & $5.789 \mathrm{~g}$ & $6.133 \mathrm{j}$ & 5.575 \\
\hline $2018-2019$ & $7.656 \mathrm{c}$ & $7.733 \mathrm{c}$ & $8.244 \mathrm{~h}$ & $8.567 \mathrm{k}$ & 8.050 \\
\hline Mean & 6.430 & 6.541 & 7.019 & 7.307 & - \\
\hline
\end{tabular}

$\mathrm{LSD}_{0.05}$ for: years - 0.097; types of foliar feeding - 0.065 ; interaction: years x types of foliar feeding -0.102 
Table 6. Green matter of the root system of one plant ( $g$ ) depending on factors of experience

\begin{tabular}{|c|c|c|c|c|c|c|c|c|}
\hline \multirow[b]{4}{*}{ Cultivars } & \multirow{3}{*}{\multicolumn{3}{|c|}{ Years }} & \multirow{2}{*}{\multicolumn{4}{|c|}{$\begin{array}{c}\text { Types of foliar feeding } \\
\text { Objects }\end{array}$}} & \multirow[b]{4}{*}{ Mean } \\
\hline & & & & & & & & \\
\hline & & & & \multirow{2}{*}{$\begin{array}{c}1 . \\
\text { Control } \\
\text { variant }\end{array}$} & \multirow{2}{*}{\begin{tabular}{|c|}
2. \\
Biostimulator \\
Aminoplant
\end{tabular}} & \multirow{2}{*}{$\begin{array}{c}3 . \\
\text { Foliar fertilizer } \\
\text { Siarkomag }+ \\
\text { foliar fertilizer } \\
\text { Bormax }\end{array}$} & \multirow{2}{*}{$\begin{array}{c}4 . \\
\text { Foliar fertilizer } \\
\text { Siarkomag + foliar } \\
\text { fertilizer Bormax }+ \\
\text { biostimulator } \\
\text { Aminoplant }\end{array}$} & \\
\hline & 2016-2017 & 2017-2018 & 2018-2019 & & & & & \\
\hline Monolit & 8.975 & 7.433 & 11.483 & 8.744 & 8.933 & 9.578 & 9.933 & $9.297 \mathrm{a}$ \\
\hline PT 248 & 8.367 & 6.875 & 10.025 & 7.956 & 8.089 & 8.600 & 9.044 & $8.422 \mathrm{~b}$ \\
\hline PX 115 & 8.275 & 6.225 & 9.100 & 7.356 & 7.511 & 8.078 & 8.522 & $7.867 \mathrm{c}$ \\
\hline Mean & $8.539 \mathrm{a}$ & $6.844 \mathrm{~b}$ & $10.203 \mathrm{c}$ & $8.019 \mathrm{a}$ & $8.178 \mathrm{~b}$ & $8.752 \mathrm{c}$ & $9.167 \mathrm{~d}$ & - \\
\hline
\end{tabular}

$\mathrm{LSD}_{0.05}$ for: years - 0.116; cultivars - 0.116 ; types of foliar feeding - 0.088 ; interaction: years $\mathrm{x}$ cultivars -0.201 ; cultivars $\mathrm{x}$ types of foliar feeding - n.s.

Table 7. Dry matter of the root system of one plant $(g)$ depending on factors of experience

\begin{tabular}{|c|c|c|c|c|c|c|c|c|}
\hline \multirow[b]{4}{*}{ Cultivars } & \multirow{3}{*}{\multicolumn{3}{|c|}{ Years }} & \multicolumn{4}{|c|}{ Types of foliar feeding } & \multirow[b]{4}{*}{ Mean } \\
\hline & & & & \multicolumn{4}{|c|}{ Objects } & \\
\hline & & & & 1. & 2. & 3. & 4. & \\
\hline & 2016-2017 & 2017-2018 & 2018-2019 & $\begin{array}{l}\text { Control } \\
\text { variant }\end{array}$ & $\begin{array}{c}\text { Biostimulator } \\
\text { Aminoplant }\end{array}$ & $\begin{array}{c}\text { Foliar fertilizer } \\
\text { Siarkomag }+ \\
\text { foliar fertilizer } \\
\text { Bormax }\end{array}$ & $\begin{array}{c}\text { Foliar fertilizer } \\
\text { Siarkomag + foliar } \\
\text { fertilizer Bormax }+ \\
\text { biostimulator } \\
\text { Aminoplant }\end{array}$ & \\
\hline Monolit & 2.075 & 1.925 & 2.975 & 2.189 & 2.233 & 2.378 & 2.500 & $2.325 \mathrm{a}$ \\
\hline PT 248 & 1.900 & 1.825 & 2.617 & 1.989 & 2.056 & 2.156 & 2.256 & $2.114 \mathrm{~b}$ \\
\hline PX 115 & 1.883 & 1.792 & 2.400 & 1.900 & 1.956 & 2.078 & 2.167 & $2.025 \mathrm{c}$ \\
\hline Mean & $1.953 \mathrm{a}$ & $1.847 \mathrm{~b}$ & $2.664 \mathrm{c}$ & $2.026 \mathrm{a}$ & $2.082 \mathrm{~b}$ & $2.204 \mathrm{c}$ & $2.307 \mathrm{~d}$ & - \\
\hline
\end{tabular}

$\mathrm{LSD}_{0.05}$ for: years -0.041 ; cultivars - 0.041 ; types of foliar feeding - 0.04 ; Interaction: years $\mathrm{x}$ cultivars -0.07 ; cultivars $\mathrm{x}$ types of foliar feeding - n.s.

\section{Conclusions}

1. Autumn foliar feeding of plants significantly increased the fresh and dry mass of the rosette and root system in comparison to the control variant. The highest growth of plant weight and root system was noted on object 4 . Biostimulator applied with foliar fertilizers had a positive effect on the uptake and accumulation of micro and macro-elements provided with foliar fertilizers.

2. Spraying plants of the Monolit variety only with the Aminoplant amino acid meant that dry and fresh mass of the aboveground part of 1 plant was at a similar level as in the control object.

3. From the compared morphotypes, the Monolit population variety was characterized by the largest green and dry mass of the rosette and root system, whereas the smallest hybrid variety with a semi-dwarf growth-type PX 115.

4. The largest fresh and dry mass of the aboveground part of rosette and root system was obtained in the warmest and driest autumn period.

Acknowledgements. The research was carried out under the research project No. 363/S/13, financed from a science grant by the Ministry of Science and Higher Education. 


\section{REFERENCES}

[1] Aisha, H., Ali. Shafeek, M. R., Mahmoud, R., Asmaa, R., El- Desuki, M. (2014): Effect of various levels of organic fertilizer and humic acid on the growth and roots quality of turnip plants (Brassica rapa). - Current Science International 3(1): 7-14.

[2] Albayrak, S., Camas, N. (2005): Effects of different levels and application times of humic acid on root and leaf yield components of forage turnip (Brassica rapa L.). - J. Agronomy 4(2): 130-133.

[3] Gawrońska, H., Przybysz, A., Szalacha, E., Słowiński, A. (2008): Physiological and Molecular Mode of Action of Asahi SL Biostimulator under Optimal and Stress Conditions. - In: Gawronska, H. (ed.) Biostimulators in Modern Agriculture. General Aspects. Wieś Jutra, Warsaw, pp. 54-76.

[4] Harris, K. D. Vanajah, T. Puvanitha, S. (2018): Effect of foliar application of boron and magnesium on growth and yield of green chilli (Capsicum annum L.). - J. Agr. SciCambridge 12(1): 26-33.

[5] Jankowski, K. J., Budzyński, W. (2007): Reaction of various winter rape cultivation forms to date and sowing density I. Autumn growth and development and wintering of plants. - Rośliny Oleiste - Oilseed Crops 28(2): 177-194 (in Polish).

[6] Jankowski, K. J., Hulanicki, P. S., Krzebietke, S., Żarczyński, P., Hulanicki, P., Sokólski, M. (2016a): Yield and quality of winter oilseed rape in response to different systems of foliar fertilization. - J. Elem. 21(4): 1017-1027. DOI: 10.5601/ jelem.2016.21.1.1108.

[7] Jankowski, K. J., Sokólski, M., Dubis, B., Krzebietke, S., Żarczyński, P., Hulanicki, P., Hulanicki, P. S. (2016b): Yield and quality of winter oilseed rape (Brassica napus L.) seeds in response to foliar application of boron. - Agricultural and Food Sci. 25: 164-176.

[8] Kocira, A., Świeca, M., Kocira, S., Złotek, U., Jakubczyk, A. (2016): Enhancement of yield, nutritional and nutraceutical properties of two common bean cultivars following the application of seaweed extract (Ecklonia maxima). - Saudi J. Biol. Sci. 25(3): 563-571. doi.org/10.1016/j.sjbs.2016.01.039.

[9] Kocoń, A. (2009): Foliar top dressing efficiency of winter wheat and rape of chosen fertilizers inoptimal fertilization and soil moisture conditions. - Annales UMCS, s. E. 64(2): 23-28 (in Polish).

[10] Kocon, A., Grenda, A. (2004): The influence of Titanite on photosynthesis, yield and nutrient uptake by rape plants. - Zesz. Probl. Post. Nauk Roln. 502(1): 49-64 (in Polish).

[11] Kotecki, A., Malarz, W., Kozak, M., Pogorzelec, A. (2007): The effect of plants' location in a canopy on the growth and yield of rape hybrids and population cultivars. Part I. Plant morphology and seed yields. - Zesz. Nauk. Uniwersytetu Przyrodniczego we Wrocławiu, Rolnictwo XC(553): 7-39 (in Polish).

[12] Krawczyk, R., Skoczyński, J. (2008): Winter Survival and Yield of Oilseed Rape Depending on Sowing Date and Application of Micronutrient Preparation Route ${ }$ Acting as a Growth Stimulator. - In: Dąbrowski, Z. T. (ed.) Monographs Series: Biostimulators in Modern Agriculture: Field Crops. Editorial House Wieś Jutra, Warsaw, pp. 33-40.

[13] Noreen, S., Fatima, Z., Ahmad, S., Athar, H. R., Ashraf, M. (2018): Plant Nutrients and Abiotic Stress Tolerance. - In: Hasanuzzaman, M., Fujita, M., Oku, H., Nahar, K., Hawrylak-Nowak, B. (eds.) Plant Nutrients and Abiotic Stress Tolerance. Springer, Singapore.

[14] Sienkiewicz-Cholewa, U., Kieloch, R. (2015): Effect of sulphur and micronutrients fertilization on yield and fat content in winter rape seeds (Brassica napus L.). - Plant, Soil and Environ. 61: 164-170.

[15] Sikorska, A., Gugała, M., Zarzecka, K., Kapela, K., Mystkowska, I. (2017): The impact of agrotechnical factors on fresh and dry matter of oilseed rape (Brassica napus L.). - J. Ecol. Eng. 18(3): 174-179.

[16] Skowera, B. (2014): Changes of hydrothermal conditions in the Polish area (1971-2010). - Fragm. Agron. 31(2): 74-87 (in Polish). 
[17] Soheir, E. El-Sherbeny, Hendawy, S. F., Youssef, A. A., Naguib, N. Y., Hussein, M. S. (2012): Response of turnip (Brassica rapa) plants to Minerals or Organic Fertilizers treatments. - J. Appl. Sci. Res. 8(2): 628-634.

[18] Szewczuk, Cz. (2003): Effect of application of chosen foliar fertilizers on winter hardiness and seed yields of winter rape. - Acta Agroph. 85: 289-295 (in Polish).

[19] Szewczuk, Cz., Sugier, D. (2009): General characteristics and types of foliar fertilizers offered on the Polish market. - Annales UMCS. s. E. LXIV(1): 29-36 (in Polish).

[20] White, C. A., Roques, S. E., Berry, P. M. (2015): Effects of foliar-applied nitrogen fertilizer on oilseed rape (Brassica napus). - J. Agri. Sci. 153(1): 42-51.

[21] Wielebski, F. (2007): Response of different types of winter oilseed rape varieties to various plant density in the field I. Seed yield and its components. - Rośliny Oleiste Oilseed Crops 28(2): 209-226 (in Polish).

[22] Wielebski, F., Wójtowicz, M. (2018): Effect of date and density of sowing and weather conditions on growth in the autumn and winter survival of winter oilseed rape morphotypes with traditional and semidraft type of growth. - Fragm. Agron. 35(2): 133145 (in Polish).

[23] World Reference Base for Soil Resources (2014): International Soil Classification System for Naming Soils and Creating Legends for Soil. Field Experiment. - FAO, WorldSoil Resources Reports, 106, Rome. http://www.fao.org.

[24] Yakhin, O. I., Lubyanov, A. A., Yakhin, I. A., Brown, P. H. (2017): Biostimulants in plant science: a global perspective. - Front. Plant Sci. 7: 2049. DOI: 10.3389/fpls.2016.02049.

[25] Złotek, U., Wójcik, W. (2014): Effect of arachidonic acid elicitation on lettuce resistance towards Botrytis cinerea. - Sci. Hortic. 179: 16-20. 